\title{
sciendo
}

CIVIL AND ENVIRONMENTAL ENGINEERING REPORTS

E-ISSN 2450-8594

CEER 2019; 29 (3): 218-227

DOI: $10.2478 /$ ceer-2019-0037

Original Research Article

\section{VARIOUS GENETIC TYPES OF END MORAINES IN THE CITY OF POZNAŃ AND ITS CLOSE VICINITY, CENTRAL-WESTERN POLAND}

\author{
Marek WIDERA ${ }^{1}$, Lilianna CHOMIAK \\ Adam Mickiewicz University, Poznań, Poland
}

\begin{abstract}
The current research focuses on explaining the origin of end moraines running through the northernmost districts of the city of Poznan. The highest hills, that is, the Moraska Hill and the Dziewicza Hill, are a stagnation record of the Vistulian Glaciation of the Poznan Phase. These two hills represent terminal moraines of similar height and age, but the mechanism of their formation is diametrically opposed. The Dziewicza Hill is a typical accumulative end moraine, where Pleistocene deposits over $70 \mathrm{~m}$ thick are undisturbed. On the other hand, the Moraska Hill is a classic example of a push end moraine with a relatively thin cover of Pleistocene sediments and glaciotectonically elevated (up to $130 \mathrm{~m}$ a.s.l.) upper Neogene deposits. In the latter case, these strongly deformed sediments are the so-called "Poznań Clays" that underlie the Quaternary deposits in the vast area of the Polish Lowlands.
\end{abstract}

Keywords: accumulative and push end moraines, depositional and deformational processes, Scandinavian ice sheets, Pleistocene of central-western Poland

\section{INTRODUCTION}

The study area covers hilly territories with a west-east course. In fact, it is consistent with the extent of the marginal zone of the Poznan Phase of the last

\footnotetext{
${ }^{1}$ Corresponding author: Adam Mickiewicz University, Institute of Geology, Krygowski st 12, 61-680 Poznań, Poland, e-mail: widera@amu.edu.pl, tel. +48618296030
} 
glaciation, that is, the Vistulian (Weichselian) glaciation (Fig. 1). Almost half of this area is within the administrative boundaries of Poznań, and half is in its close vicinity. The research area, in almost equal parts, is located on both banks of the Warta River, which flows longitudinally through Poznań City and crosses the above-mentioned marginal zone. As a result, the highest culminations (i.e., the Moraska and Dziewicza hills) belonging to the aforementioned end-moraine zone, are situated on the west and east banks of the Warta River, respectively (Fig. 1).

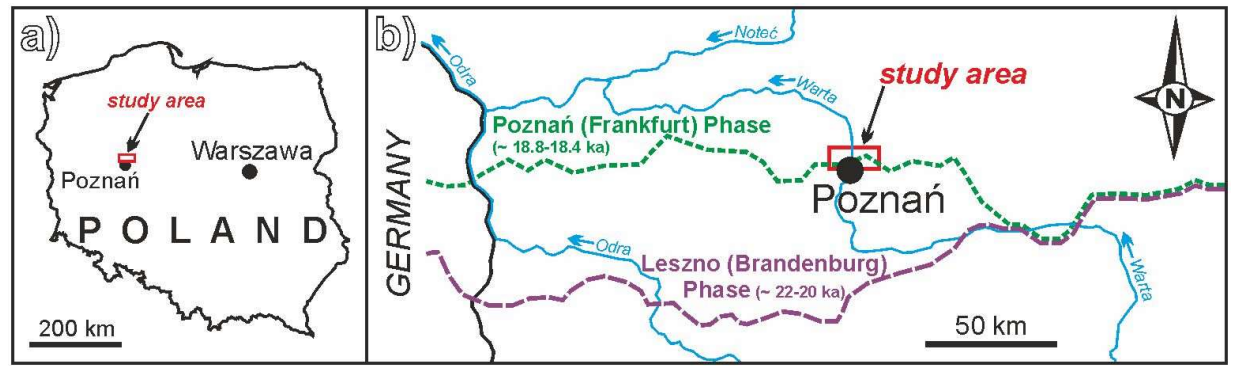

Fig. 1. Location map: a) study area in the background of Poland, b) study area against the background of the Leszno and Poznan phases of the Vistulian (Weichselian) Glaciation in central-western Poland $[6,8]$

Both the Moraska Hill and the Dziewicza Hill have many similarities: age, morphology (height, slope inclination, etc.) and general glaciogenic origin. Nevertheless, their internal structure is significantly different. Therefore, the main aim of this study is to describe and then explain the mechanisms that led to the creation of these two types of end moraines of the same age and located in relatively close proximity to each other.

channel-fill sands and muds.

\section{GEOLOGICAL AND GEOMORPHOLOGICAL SETTING}

The study area is located in a very interesting geological as well as geomorphological position. Therefore, geology and geomorphology will first be briefly described, and then the issues of the impact of tectonics sensu stricto on the formation of modern morphology in the vicinity of the northern districts of Poznań will be identified.

\subsection{Outline of geology}

The research area belongs to two main structural-tectonic units of Poland, that is, to the Szczecin-Miechów Synclinorium and the Fore-Sudetic Monocline (Fig. 2a, b). In the previous case, where the Mesozoic top is made up of 
Cretaceous rocks, the Miechów Synclinorium is divided into the SzczecinGorzów and Mogilno-Łódź segments [20]. However, most inspiring is the fact that three important fault zones connect just north of the Moraska and Dziewicza hills: Poznań-Szamotuły, Poznań-Oleśnica and Poznań-Kalisz fault zones (Fig. 2b) [3-5, 15-18].

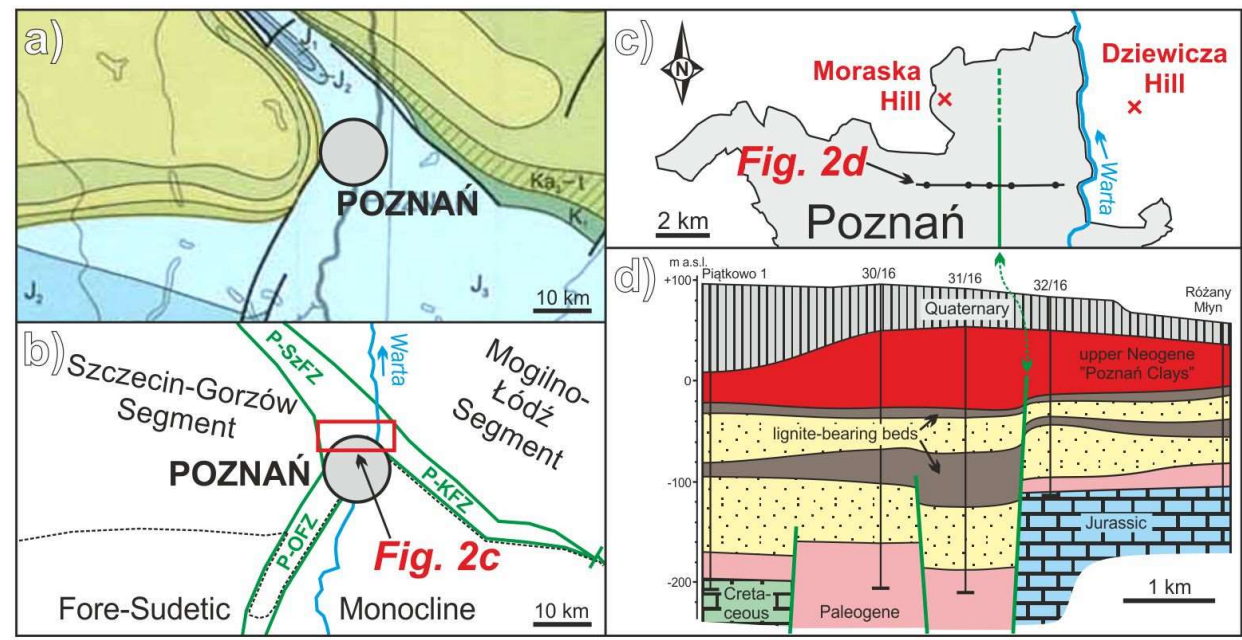

Fig. 2. Geological location of the study area: a) stratigraphy of the sub-Cenozoic surface [3], b) major tectonic units and structures: P-SzFZ - Poznań-Szamotuły Fault Zone, P-OFZ - Poznań-Oleśnica Fault, P-KFZ - Poznań-Kalisz Fault Zone [3-5, 15-18,

20], c), location of the cross-section depicted in Fig. 2d, d) generalised Cenozoic geology of the area between the Moraska and Dziewicza hills [12]; for location of the cross-section line see Fig. 2c

In the territory between the two hills, on the left bank of the Warta River and almost parallel to it, runs the eastern graben-bounding fault (or fault zone) of the Poznań-Oleśnica Fault Zone (Fig. 2c, d). Its vertical throw reaches over $175 \mathrm{~m}$ [12], along which Mesozoic as well as Paleogene and Neogene rocks are displaced. To achieve the aims of this paper, the youngest Neogene deposits, the so-called "Poznań Clays," are the most important. In the area under study, they have an average thickness of 30-70 m (Fig. 2d), and often comprise relatively thick (up to $35 \mathrm{~m}$ ) sandy bodies, which are interpreted as fillings of fluvial palaeochannels $[9,14]$.

\subsection{Outline of geomorphology}

The Moraska and Dziewicza hills are high ca. 154 and $143 \mathrm{~m}$ a.s.l., respectively. They are surrounded by ground moraine and sandurs, which are at an altitude of 80-100 m a.s.l. (Fig. 3) [7, 19]. Thus, their relative heights in relation to the surrounding areas are up to $50 \mathrm{~m}$ (Fig. 4). 


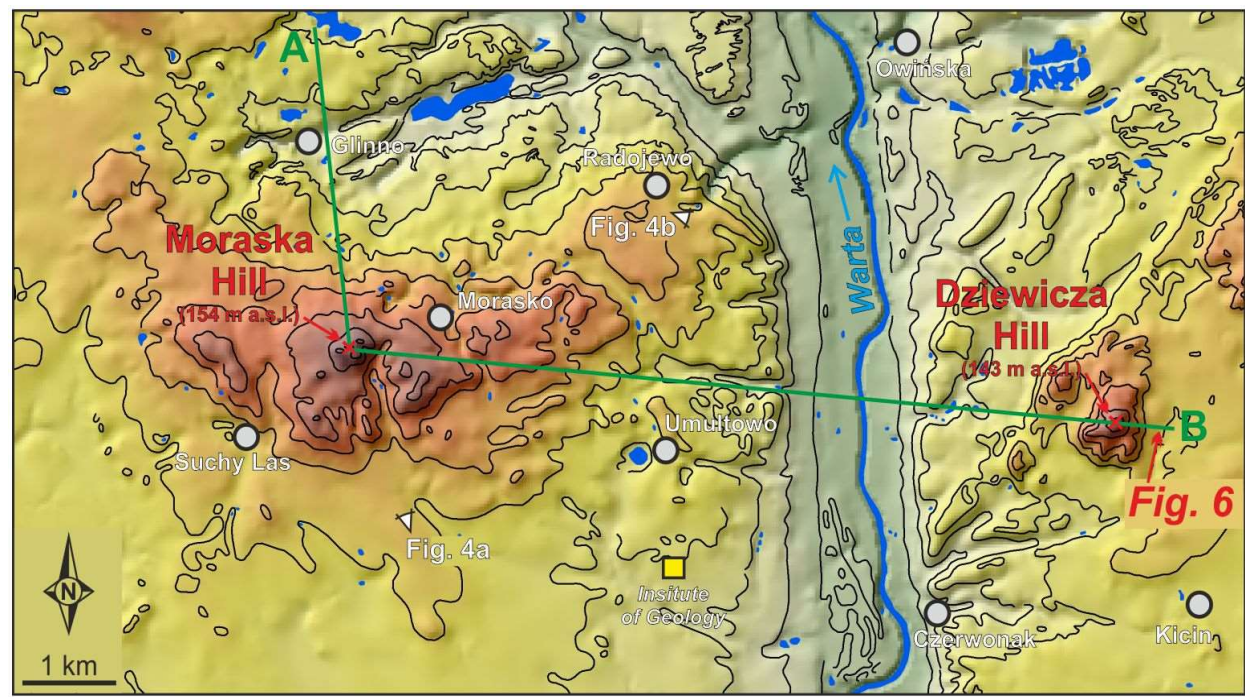

Fig. 3. Digital elevation model (DEM) of the Moraska and Dziewicza hills (prepared by W. Włodarski for [13])

The study area is cut longitudinally by the Warta River, which separates the Moraska and Dziewicza hills. Here, the Warta River creates a gap section that is called the Poznan Warta Gap $[1,2,18]$. Between the examined hills, the river is ca. $1.5-2 \mathrm{~km}$ wide, while its bottom is at an altitude of ca. $50 \mathrm{~m}$ a.s.l. Due to the fact that the Dziewicza Hill is $2 \mathrm{~km}$ away from the Warta River, and the Moraska Hill is more than $5 \mathrm{~km}$, Dziewica is more visible (Fig. 4).

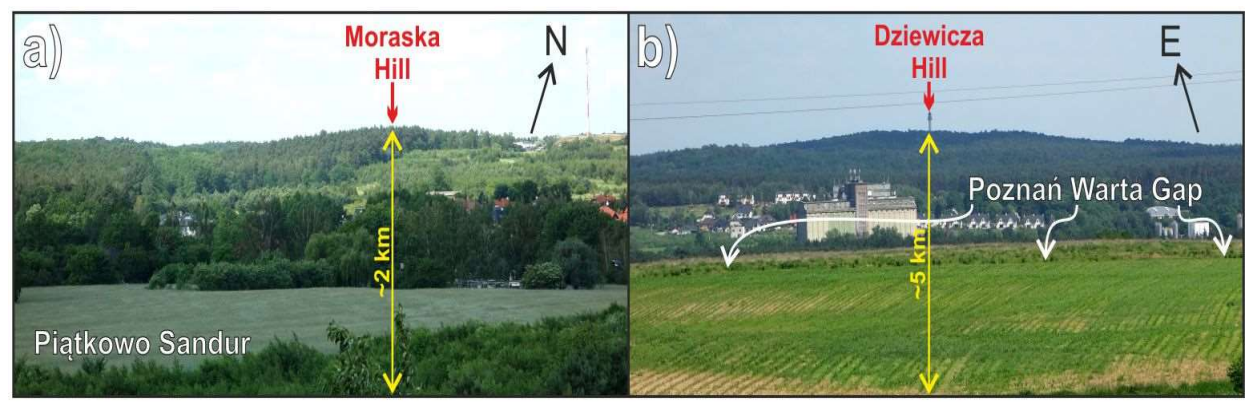

Fig. 4. Broad view of the studied forms: a) northward view of the Moraska Hill, b) eastward view of the Dziewicza Hill

\section{DATA AND METHODS}

The stratigraphy of the Vistulian (Weichselian) deposits is based on data from geological maps and explanations to them $[2,8,10,11]$. Figures 5 and 6 are 
prepared on materials (mainly boreholes) that originally come from the National Geological Archive and Central Geological Database of the Polish Geological Institute - National Research Institute in Warsaw, Poland.

However, the most important research method used in this work to explain the origin of different types of end moraine is the palaeomorphological analysis of the top of the "Poznań Clays" (Figs. 5, 6). These Mio-Pliocene fine-grained deposits are widely spread and relatively easy to identify both in boreholes and in the field [9].

\section{STUDY RESULTS}

The results obtained will be presented in a specific order. First, the geological structure of the Dziewicza Hill and then the Moraska Hill will be described and interpreted (Figs. 5, 6). Finally, new conceptual models for the creation of both studied hills will be proposed (Fig. 7).

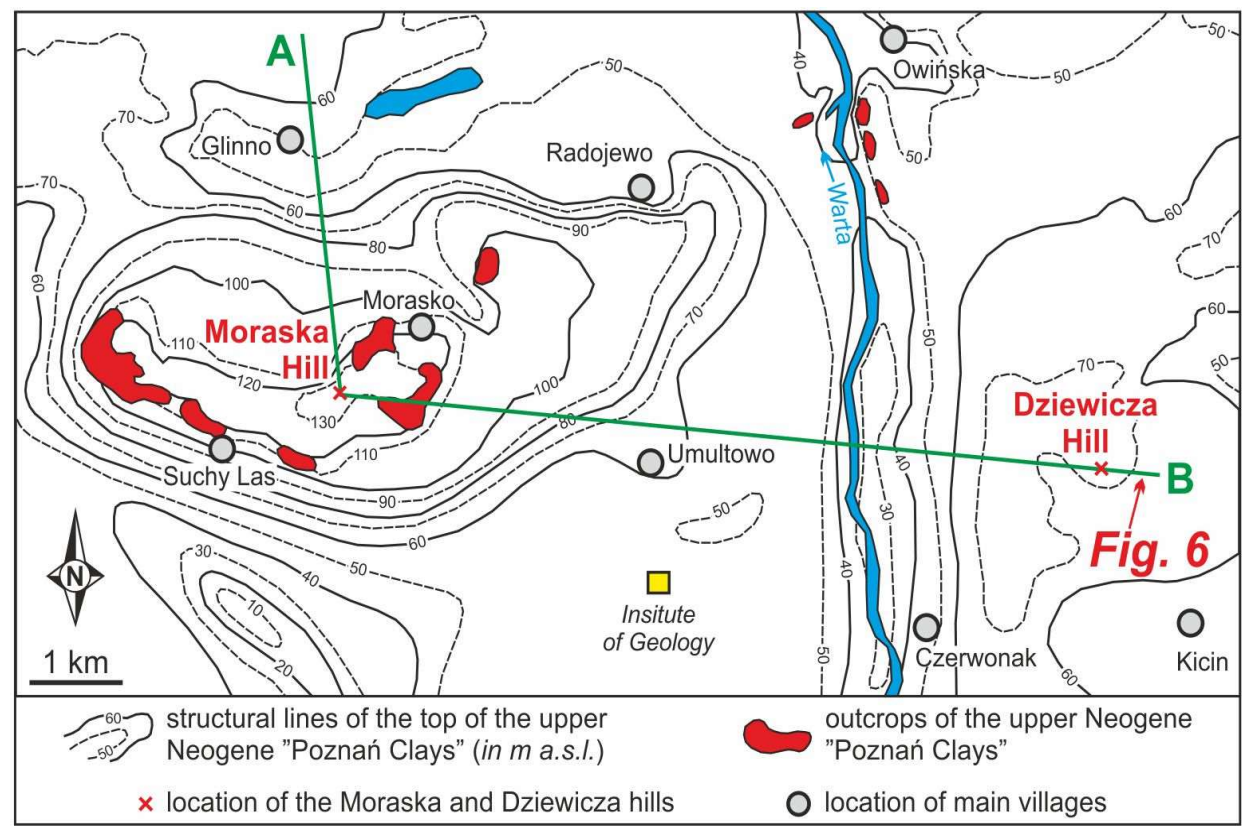

Fig. 5. Structural map of the top of the upper Neogene "Poznan Clays" [2, 13]

\subsection{Dziewicza Hill - accumulative end moraine}

Description. The Dziewicza Hill is located on the right bank of the Warta River. The Quaternary bedrock is built of the "Poznań Clays" that lie quite flat at a height of 60-70 m a.s.1. (Figs. 5, 6). Above are Quaternary deposits, mainly 
of Pleistocene age. They represent the following glaciations: Elsterian, Saalian and Weichselian (Vistulian). The vast majority of the Dziewicza Hill is made up of fluvioglacial sediments (sands and gravels), among which the Vistulian tills occur sporadically, creating thin lenses (Fig. 6).

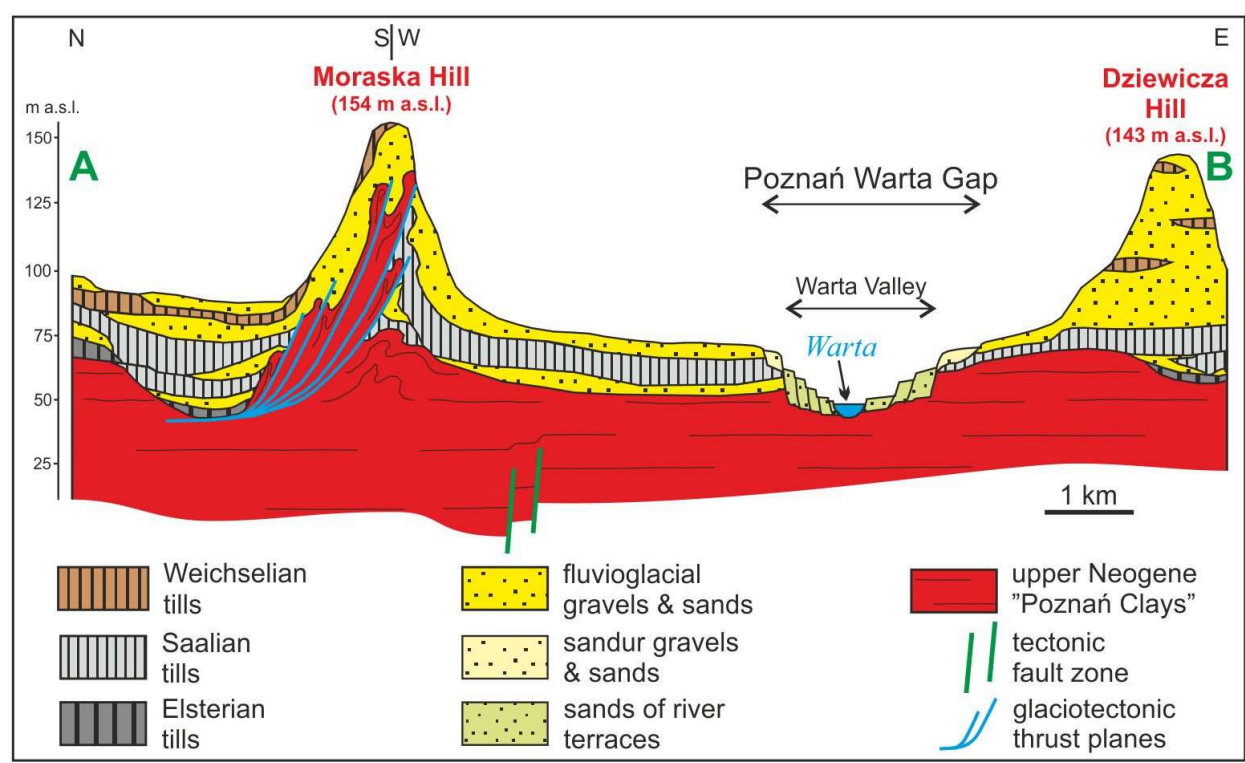

Fig. 6. Cross-section through the area between the Moraska and Dziewicza hills [10, 11, 13]; for location of the cross-section line A-B see Figs. 3, 5

Interpretation. Analysing the shape of the "Poznań Clays" top and the inner structure of the Dziewicza Hill, it can be stated that the sediments of the upper Neogene and Pleistocene have not been noticeably deformed syn- and/or postdepositionally. Therefore, the Dziewicza Hill should be considered as a typical accumulative end moraine. Most likely, it was created in front of the forehead of the stagnant (sub-)lobe of the Scandinavian ice sheet (Fig. 7a, d) [17].

\subsection{Moraska Hill - push end moraine}

Description. The Moraska Hill is located on the right bank of the Warta River. Generally, the same sediments as mentioned above are present in this case (Fig. 6). However, in contrast to the area of the Dziewicza Hill, both the Quaternary bedrock and the Pleistocene glaciogenic deposits are strongly deformed. This is particularly visible at high elevation in the "Poznan Clays" a height above 130 m a.s.l. (Figs. 5, 6). Obviously, tills of older glaciations, such as the Saalian glaciation, are also elevated near the surface (Fig. 6). 
Interpretation. The formation of the Moraska Hill must be explained differently than the creation of the Dziewicza Hill. This is due to macroscale glaciotectonic deformations that have been documented in the area of the Moraska Hill (cf. Figs. 5 and 6). These deformations arose in the marginal zone by pushing the rock

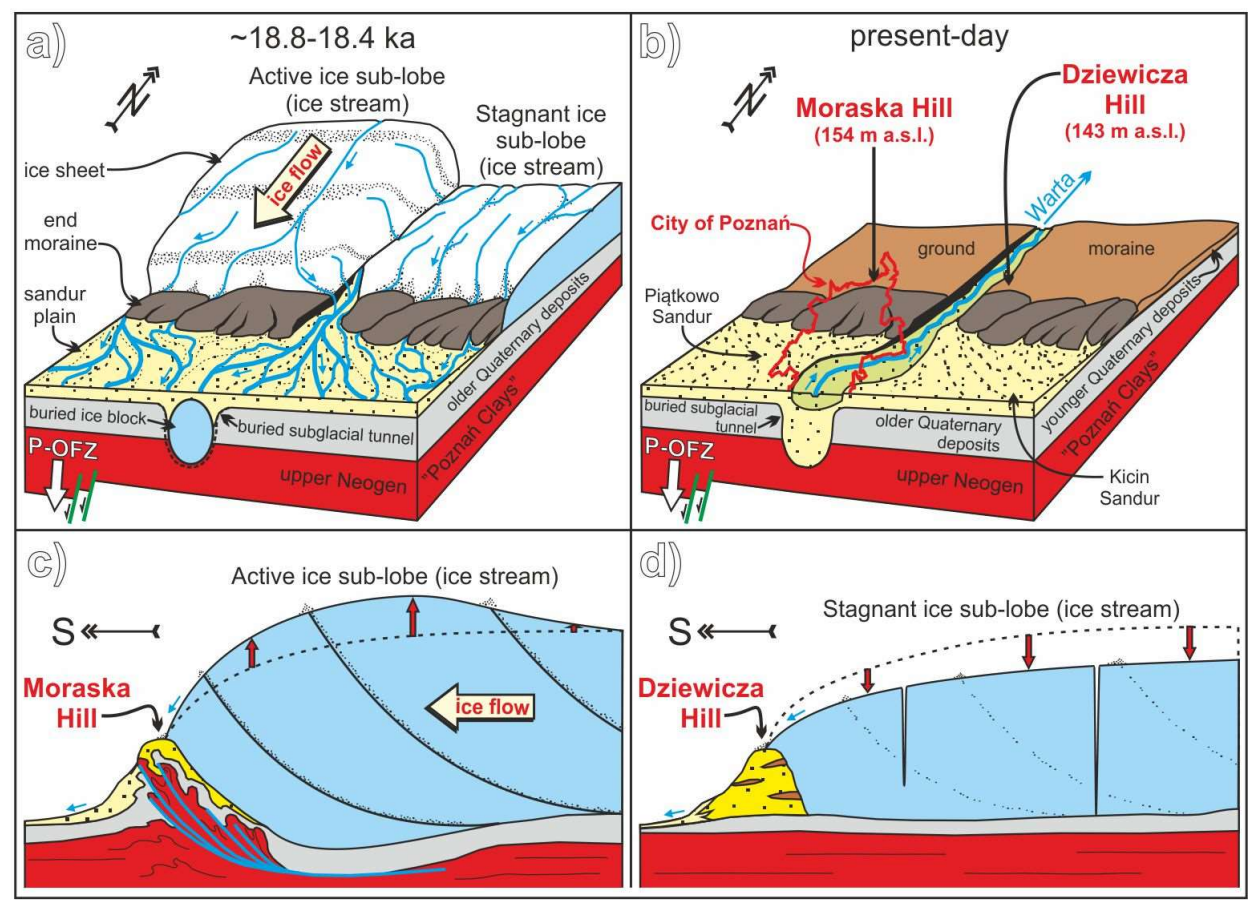

Fig. 7. Conceptual models depicting the formation of the push (Moraska Hill) and accumulative (Dziewicza Hill) end moraines: a) and b) blockdiagrams, c) and d) crosssections [17]; for other explanations see Figs. 3, 5 and the text

material from under the ice sheet onto its foreland. In this case, the increase in vertical stress, caused by the weight of the ice column (i.e., glaciostatic pressure), has probably played the most important, destructive role. Such a situation is characteristic of an active (sub-)lobe, when new masses of ice flow into its marginal zone (Fig. 7a, c). As a result of the increasing thickness of the ice sheet, the stress on the substratum exceeded the strength of the disturbed basal deposits, predominantly the upper Neogene "Poznan Clays" (cf. Figs. 5, 6, 7c). In conclusion, the Moraska Hill is one of the best examples of a push end moraine in Poland $[2,6-8,10,11,13,17,20]$. 


\section{FINAL REMARKS}

The Dziewicza and Moraska hills are the highest hills in close vicinity of Poznań. They represent terminal moraines of the Poznan Phase of the Vistulian Glaciation. Furthermore they are characterised by similar height and age, but have opposite mechanisms of formation.

The Dziewicza Hill is widely recognised as an accumulative end moraine, while the Moraska Hill is unquestionably a push end moraine. The previous one probably came into being in front of the forehead of the stagnant (sub-)lobe. In contrast, the formation of the latter one is most likely associated with an active (sub-)lobe, whose increasing thickness in the marginal zone caused glaciotectonic uplift and deformation of older sediments, including the "Poznań Clays."

So far, the relationship between the bedrock geology and geomorphology has not been convincingly explained in the study area. In this case, it is the parallelism of the deeply-rooted fault zone and the Poznań Warta Gap (cf. Figs. 2, 6 and 7a, b). Thus, the solution of this interesting geological-geomorphological research problem will also contribute to the full explanation of the creation of the aforementioned Poznan Warta Gap between active and stagnant (sub-)lobes of the Scandinavian ice sheet.

\section{ACKNOWLEDGEMENTS}

We are deeply grateful to the anonymous reviewers of this article.

\section{REFERENCES}

1. Bartkowski, T 1957. The development of post-glacial hydrographic network in cenntal Wielkopolska (Rozwój polodowcowej sieci hydrograficznej w Wielkopolsce środkowej). Zeszyty Naukowe UAM, Seria Geografia 1, 3-79.

2. Chmal, R 1990. Detailed geological map of Poland at scale 1: 50 000, Poznań sheet (Szczegółowa mapa geologiczna Polski w skali 1:50 000, arkusz Poznań). Państwowy Instytut Geologiczny, Warszawa.

3. Dadlez, R, Marek, S and Pokorski, J 2000. Geological map of Poland without Cenozoic deposits at scale 1:1000 000 (Mapa geologiczna Polski bez utworów kenozoiku 1:1000 000). Państwowy Instytut Geologiczny, Warszawa.

4. Deczkowski, Z and Gajewska, I 1980. Mesozoic and Tertiary troughs in the Fore-Sudetic Monocline (Mezozoiczne i trzeciorzędowe rowy obszaru monokliny przedsudeckiej). Przeglad Geologiczny 28, 151-156.

5. Kasiński, JR 1984. Synsedimentary tectonics as the factor determining sedimentation of brown coal formation in tectonic depressions in western Poland (Tektonika synsedymentacyjna jako czynnik warunkujacy 
sedymentacje formacji burowęglowej $w$ zapadliskach tektonicznych na obszarze zachodniej Polski). Przeglad Geologiczny 32, 260-268.

6. Kozarski, S 1986. Time scales and the rhythm of Vistulian geomorphic events in the Polish Lowland (Skale czasu a rytm zdarzen geomorfologicznych vistulianu na Niżu Polskim). Czasopismo Geograficzne 57, 247-270.

7. Krygowski, B 1961. Physical geography of the Wielkopolska Lowland. Part I. Geomorphology (Geografia fizyczna Niziny Wielkopolskiej. Cz. I. Geomorfologia). Poznańskie Towarzystwo Przyjaciół Nauk, Wydział Matematyczno-Przyrodniczy, Poznań.

8. Marks, L, Ber, A, Gogołek, W and Piotrowska, K 2006. Geological map of Poland at scale 1:500 000 (Mapa geologiczna Polski w skali 1:500 000). Państwowy Instytut Geologiczny, Warszawa.

9. Maciaszek, P, Chomiak, L, Urbański, P and Widera, M 2020. New insights into the genesis of the "Poznan clays" - upper Neogene of Poland. Civil and Environmental Engineering Reports 31, in review.

10. Pielach, M and Tomaszczyk, M 2019. Geological map of Poland at scale 1:100 000, Poznań sheet (Mapa geologiczna Polski w skali 1:200 000, arkusz Poznań). Państwowy Instytut Geologiczny, Warszawa.

11. Skompski, S 1994. Quaternary geology near Oborniki, central Great Poland Lowland, with references to palaeontological data. Folia Quaternaria $\mathbf{6 5}$, 285-302.

12. Widera, M 2007. Lithostratigraphy and Palaeotectonics of the sub-Pleistocene Cenozoic of Wielkopolska (Litostratygrafia i paleotektonika kenozoiku podplejstoceńskiego Wielkopolski). Seria Geologia, 18, Wydawnictwo Naukowe UAM, Poznań.

13. Widera, M 2009. Cenozoic geology of the Polish Lowlans. Guide to field exercises in Cenozoic geology and geomorphology (Geologia kenozoiku Nizu Polskiego. Przewodnik do ćwiczeń terenowych z geologii kenozoiku $i$ geomorfologii). Wydawnictwo Naukowe UAM, Poznań.

14. Widera, M 2012. Fluvial origin of the Wielkoposka Member based on data from the central Poland (Fluwialna geneza ogniwa wielkopolskiego na podstawie danych z obszaru środkowej Polski). Górnictwo Odkrywkowe 53, 109-118.

15. Widera, M, Banaszak, J, Cepińska, S and Derdowski, R 2004. Palaeotectonic analysis of the Paleogene and Neogene activity of the northern parts of the Poznañ-Oleoenica Dislocation Zone. (Analiza paleotektoniczna paleogeńskiej $i$ neogeńskiej aktywności pólnocnych fragmentów strefy dyslokacyjnej Poznań-Oleśnica). Przeglad Geologiczny 52, 665-674.

16. Widera, M, Cwikliński, W and Karman, R 2008. Cenozoic tectonic evolution of the Poznań-Oleśnica Fault Zone, central-western Poland. Acta Geologica Polonica 58, 455-471. 
17. Widera, M and Chomiak, L 2019. The diverse origin of the terminal moraine of the same age - an example from around the city of Poznań. CGE-2019 Proceedings of the third International Conference "Challenges in Geotechnical Engineering." September 10th-13th 2019, Zielona Góra, Poland, 37.

18. Widera, M and Karman, R 2007. Location of the major eastern fault in the Mesozoic substratum of the City of Poznań (Lokalizacja wschodniego uskoku głównego w mezozoicznym podlożu Poznania). Przegląd Geologiczny 55, 965-970.

19. Zwoliński, Z, Hildebrandt-Radke, I, Mazurek, M and Makohonienko, M 2017. Existing and proposed urban geosites values resulting from geodiversity of Poznań City. Quaestiones Geographicae 36, 125-149.

20.Żelaźniewicz, A, Aleksandrowski, P, Buła, Z, Karnkowski, PH, Konon, A, Oszczypko, N, Ślączka, A, Żaba, J and Żytko, K 2011. Tectonic division of Poland (Regionalizacja tektoniczna Polski). Komitet Nauk Geologicznych Polska Akademia Nauk, Wrocław.

Editor received the manuscript: 23.09.2019 